\title{
REAL ESTATE MARKET IN THE RUSSIAN FEDERATION IN Q1 2013
}

\author{
G.Zadonsky
}

126,100 apartments covering a total of 10.4 million square meters floor space were constructed in Q1 2013, accounting for 106.5\% against Q1 2012. Average actual cost of construction of 1 square meter in the housing total floor space increased 7.89\% in Q1 2013 vs. Q1 2012 and amounted to Rb 34,920. The ratio of the price of 1 square meter of residential floor space in the total floor space in the primary housing market to the cost of construction of 1 square meter of the residential floor space increased by 0.85 p.p. over the same period and stood at $139.75 \%$. State registration of land title for individuals (1,243m title deeds) increased $6.24 \%$ in volumes in Q1 2013 vs. Q1 2012. 211480 housing mortgage loans (HMLs), Rb 341,0bn, were issued from January to April 2013, showing an increase of 27.52\% vs. April 2012. In April 2013, monthly growth in the weighted average interest rate on ruble HMLs gave way to a decline for the first time since November 2011. The interest rate decreased 0.3 p.p., falling to $12.6 \%$.

According to the Federal State Statistics Service of Russia (Rosstat), organizations of all types of incorporation constructed 126,100 apartments covering a total of 10.4 million sq. $\mathrm{m}$ floor space, accounting for $106.5 \%$ year on year, of which individual developers constructed residential buildings covering 5.34 million square meters of floor space in Q1 2013, accounting for $101.7 \%$ vs. Q1 2012 and $51.4 \%$ of the total volume of buildings commissioned in Q1 2013 (Fig. 1). 46,500 new apartments covering a total of 3.71 million sq. $\mathrm{m}$ floor space were constructed in April 2013, or $126.9 \%$ vs. April 2012.

Average actual cost of construction of 1 square meter of housing total floor space amounted to $\mathrm{Rb} 34,920$ in Q1 2013 (Fig. 2), showing an increase of $7.89 \%$ vs. Q1 2012 ( $R b$ 32,366 in Q1 2012). Average price of 1 square meter of housing total floor space in the primary housing market increased 8.44\% in Q1 2013 ( $\mathrm{Rb} 48,800)$ vs. Q1 2012, remaining lower than average price $(\mathrm{Rb} 55,400)$ of 1 square meter of housing total floor space in the secondary housing market which also increased vs. Q1 2012. In addition, the ratio of the price of 1 square meter of housing total floor space in the primary housing market as a percentage of the cost of construction of 1 square meter of housing floor space increased 0.85 p.p. in Q1 2013 and grew up to $139.75 \%$ vs. Q1 2012 (Fig. 2).

According to Rosstat, the Nenets Autonomous District ( $\mathrm{Rb}$ 55617) and Yamalo-Nenets Autonomous District ( $\mathrm{Rb} 51470$ ) had the highest cost of construction, being 1.5x and more the Russian average, in Q1 2013; 51 constituent territories of the Russian Federation showed below the Russian average cost, of which the Republic of Dagestan (Rb 17210), Penza Region (Rb 22019) and Zabaikalye Territory (Rb 22309) had lowest costs.

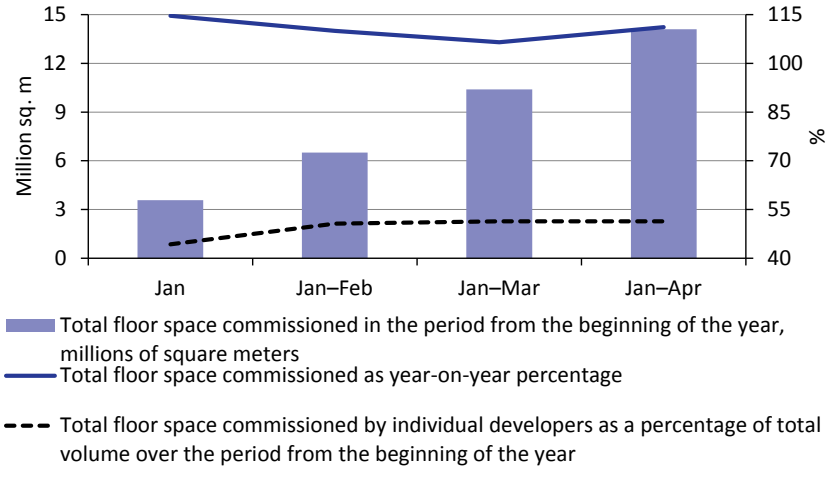

Source: based on the data provided by Rosstat.

Fig. 1. Dynamics of housing commissioning as progressive total from the beginning of 2013

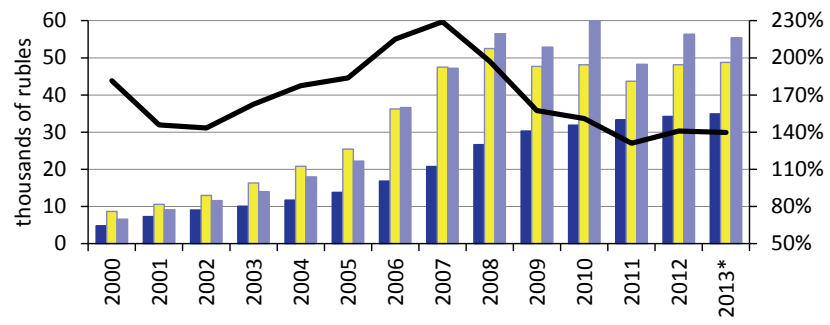

Average actual cost of construction of $1 \mathrm{sq} . \mathrm{m}$ of housing total floor space ${ }^{* *}$ thousands of rubles

$\square$ Average price of 1 sq. $m$ of housing total floor space in the primary housing market***, thousands of rubles

Average price of $1 \mathrm{sq}$. $\mathrm{m}$ of housing total floor space in the secondary housing market***, thousands of rubles

* Q1 2013;

** average actual price of construction of 1 square meter of housing total floor space of detached residential buildings (all apartments) without extensions, integral and attached premises;

$* * *$ all apartments.

Source: based on the data provided by Rosstat.

Fig. 2. Dynamics of the cost of construction of 1 square meter of housing total floor space and the price of 1 square meter of housing total floor space in the primary and secondary housing markets in the Russian Federation 
According to the Russian State Register, B Q1 2013 the number of registered individuals' titles to living quarters (2159456 title deeds) increased $16.28 \%$ vs. Q1 2012 (Fig. 3), whereas the number of registered legal entities' titles to living quarters (42147 title deeds) decreased 8.63\% vs. Q1 2012.

According to the Russian State Register, the volume of state registrations of land title for individuals (1243811 title deeds) increased 6.24\% in Q1 2013 vs. Q1 2012 (Fig. 4). The number of state registrations of land title for legal entities contracted $3.44 \%$ to amount to 60145 title deeds in Q1 2013. Leasehold of land plots by individuals (16322 leasehold deeds) contracted 1.16\% in Q1 2013 vs. Q1 2012, whereas leasehold of land plots by legal entities increased by 3.9 times (41996 leasehold deeds) over the same period.

According to the Russian State Register, the volume of simplified state registrations of title to certain types of immovable property ("country house amnesty") most of which are land plots which were registered prior to the introduction of the Land Code of the Russian Federation for private subsidiary farming, country-house, home gardening, private garage or housing construction, tends to decline (Fig. 4). In Q1 2013, the volume of simplified state registrations of title to certain types of immovable property amounted to 210281 title deeds, being $13.42 \%$ less than in Q1 2012, including 106928 title deeds of simplified state registration of land, being 12.95\% less than in Q1 2012.

The number of mortgaged land plots registered in Q1 2013 increased $15.40 \%$ for physical bodies (95699 mortgage deeds) and $14.45 \%$ for legal entities (33035 mortgage deeds) against Q1 2012.

The number of housing mortgages contracted 4.93\% in Q1 2013 (235284 mortgage deeds) against Q1 2012. In addition, the number of mortgages on living quarters owned by individuals that were purchased (constructed) through borrowed funds or a special-purpose loan in Q1 2013 (168993 mortgage loans) increased 14.58\% against Q1 2012 (Fig. 5).

According to the Central Bank of Russia, 224217 housing loans (HLs) at Rb 351,524bn were issued from January to April 2013, including 211480 housing mortgage loans (HMLs) at Rb $341,0 b n$, exceeding by $27.52 \%$ the amount of HMLs issued from January to April 2012.

A total of $\mathrm{Rb} 111,91 \mathrm{bn}$ of ruble HMLs were issued in April 2013, being 27.28\% more than in April 2012 (Fig. 6), Rb 2,101bn of foreign currency HMLs, being 71.93\% more than in April 2012 (Fig. 7). In April 2013, outstanding debt on ruble HMLs increased $3.37 \%$ to reach $\mathrm{Rb} 2,042$ trillion, whereas outstanding debt on foreign currency loans contracted $0.24 \%$ to $\mathrm{Rb} 118,9 \mathrm{bn}$.

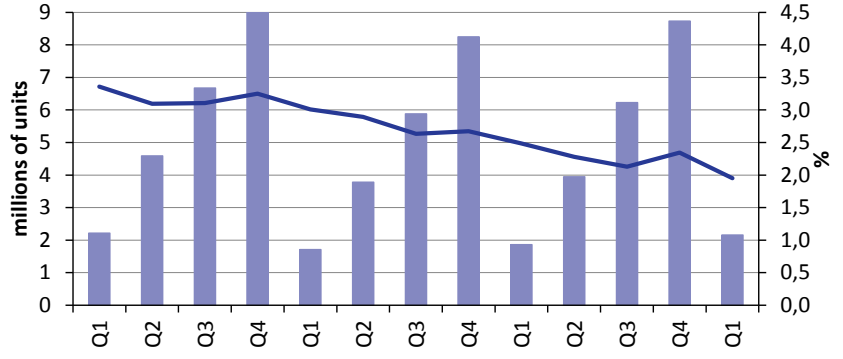

Volume of state registrations of land title for individuals, millions of units

Volume of state registrations of land title for legal entities as a percentage of the volume of state registrations of land title for individuals

Source: based on the data provided by the Russian State Register.

Fig. 3. Dynamics of state registration of title to living quarters

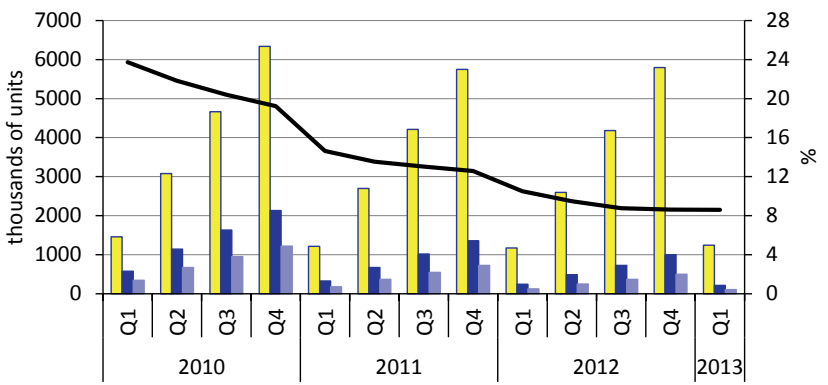

$\square$ Registration of title to land plots (total) for individuals, thousands of units

Simplified registration of title to certain types of immovable property (total) for individuals, thousands of units

Simplified registration of title to land plots for individuals, thousands of units

- Simplified registration of title to land plots for individuals as a percentage of registration of title to land plots (total) for individuals

Source: based on the data provided by the Russian State Register.

Fig. 4. Dynamics of state registration of title to land plots for individuals

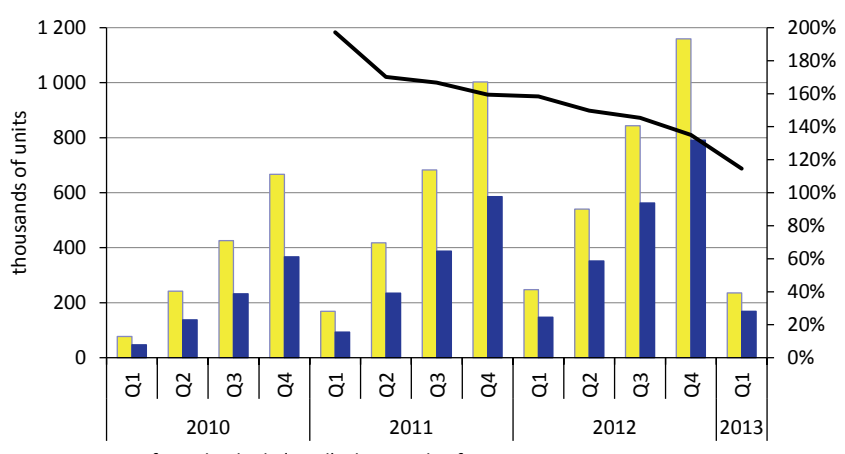

Mortgage for individuals (total), thousands of units

Mortgage on living quarters purchased (constructed) by individuals through borrowed funds or a special-purpose loan, thousands of units

-Mortgage on living quarters purchased (constructed) by individuals through borrowed funds or a special-purpose loan as a percentage of the respective period of the preceding year

Source: based on the data provided by the Russian State Register.

Fig. 5. Dynamics of state registration of housing mortgage 
Beginning with October 2011, average monthly value of ruble HMLs increased $25.69 \%$ and amounted to $\mathrm{Rb}$ 1,625m as of May 1, 2013 (Fig. 6). Monthly average amount of foreign currency HMLs followed no steady trend at the same period, amounting to $\mathrm{Rb} 9,296 \mathrm{~m}$ in April2013, being 41.39\%higherthan in March 2013(Fig. 7). Late payments on HMLs as of May 1, 2013 (Rb 42,159bn, of which ruble loans amounted to Rb 27,94bn (Fig. 6) and foreign currency loans to Rb 14,219bn (Fig. 7)) decreased $5.42 \%$ vs. as of May 1, 2012. Late payments as a percentage of outstanding debt declined steadily at the same period and stood at $1.95 \%$ as of May 1, 2013, being 0.86 p.p. less than as of May 1, 2012.

Late payments as a percentage of outstanding debt due on ruble HMLs declined steadily and stood at $1.37 \%$ as of May 1, 2013, being 0.39 p.p. less than as of May 1, 2012. Late payments on foreign currency HMLs as a percentage of outstanding debt increased again after a fall to $11.42 \%$ in December 2012, and stood at $11.96 \%$ as of May 1, 2013.

According to the Central Bank of Russia, as of May 1, 2013, the debt on defaulted HMLs (with a delay period longer than 180 days) amounted to $\mathrm{Rb} 26,143 \mathrm{bn}$ and accounted for $1.21 \%$ of total debt owed, being 0.23 p.p. less than in the previous month (Table 1). A share of debt on HMLs without late payments decreased by 0.23 p.p. and accounted for $95.96 \%$ of the total amount of debt on HMLs as of May 1, 2013 vs. April 1, 2013 (Table 1).

Weighted average interest rates on ruble HMLs and $\mathrm{HLS}$ issued during that month stopped growing at 12.9\% in March 2013 (Fig. 8). In April 2013, weighted average interest rate on HMLs declined to $12.6 \%$, and on HLs to $12.7 \%$. Weighted average interest rates on HMLs and foreign currency HLs issued during the year became equal at $10.0 \%$ as of May 1, 2013.

Weighted average periods for ruble loans issued during the month decreased in April 2013 vs. March 2013: to 14.9 years for HMLs and 14.7 years for HLs

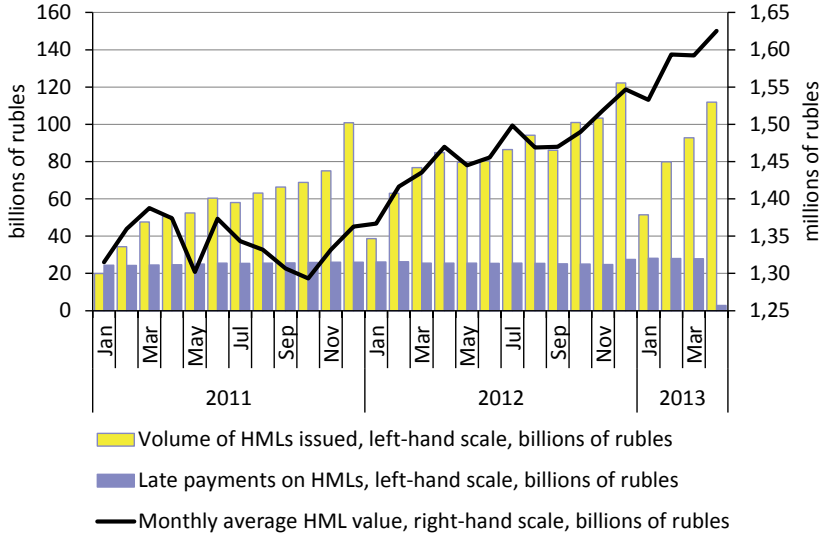

Source: based on the data provided by the Central Bank of Russia.

Fig. 6. Dynamics of ruble housing mortgage loans

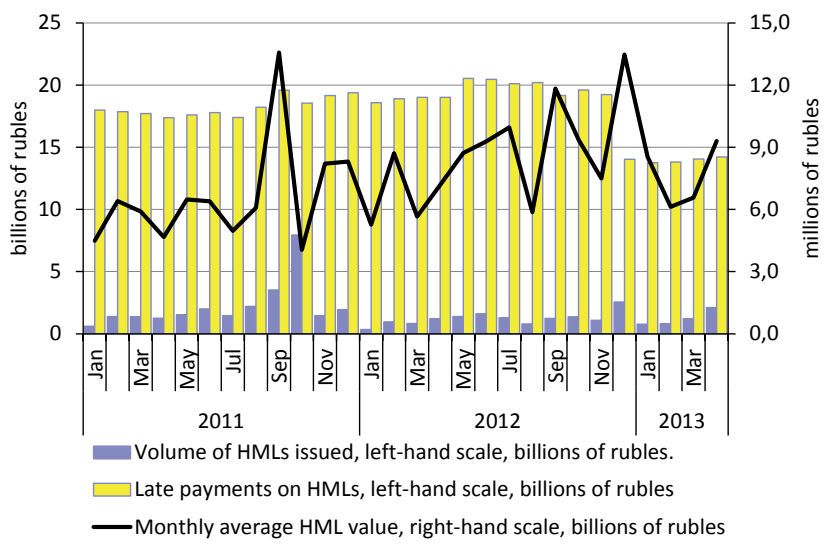

Source: based on the data provided by the Central Bank of Russia.

Fig. 7. Dynamics of foreign currency housing mortgage loans

(Fig. 8). Weighted average period of lending for foreign currency HMLs issued year-to-date was 12.48 years in April 2013, and 10.66 years for foreign currency HLs.

In 2013, a share of foreign currency HMLs in the outstanding debt kept declining like it did in 2012, and stood at $5.5 \%$ as of May 1, 2013, being 3.14 p.p. less

Table 1

BREAK-DOWN OF DEBT ON HOUSING MORTGAGE LOANS BY PERIOD OF DELAYED PAYMENT IN 2013

\begin{tabular}{|c|c|c|c|c|c|c|c|c|c|}
\hline \multirow{4}{*}{2013} & \multirow{4}{*}{$\begin{array}{l}\text { Total amounts } \\
\text { owed on HMLs } \\
\text { millions of rubles }\end{array}$} & \multicolumn{8}{|c|}{ Including } \\
\hline & & \multirow{2}{*}{\multicolumn{2}{|c|}{ without late payments }} & \multicolumn{6}{|c|}{ with late payments } \\
\hline & & & & \multicolumn{2}{|c|}{1 to 90 days } & \multicolumn{2}{|c|}{91 to 180 days } & \multicolumn{2}{|c|}{ more than 180 days } \\
\hline & & $\begin{array}{c}\text { millions of } \\
\text { rubles }\end{array}$ & $\% *$ & $\begin{array}{l}\text { millions } \\
\text { of rubles }\end{array}$ & $\% *$ & $\begin{array}{l}\text { millions } \\
\text { of rubles }\end{array}$ & $\% *$ & $\begin{array}{l}\text { millions } \\
\text { of rubles }\end{array}$ & $\% *$ \\
\hline 01 Jan & $1,997,204$ & $1,915,917$ & 95.93 & 30,957 & 1.55 & 5,193 & 0.26 & 45,137 & 2.26 \\
\hline 01 Feb & $2,010,608$ & $1,928,374$ & 95.91 & 47,048 & 2.34 & 5,228 & 0.26 & 29,958 & 1.49 \\
\hline $01 \mathrm{Mar}$ & $2,052,696$ & $1,965,046$ & 95.73 & 53,165 & 2.59 & 5,542 & 0.27 & 28,943 & 1.41 \\
\hline $01 \mathrm{Apl}$ & $2,094,420$ & $2,014,622$ & 96.19 & 43,983 & 2.10 & 5,655 & 0.27 & 30,160 & 1.44 \\
\hline 01 May & $2,160,601$ & $2,073,313$ & 95.96 & 55,095 & 2.55 & 6,050 & 0.28 & 26,143 & 1.21 \\
\hline
\end{tabular}

* of total amounts owed.

Source: data provided by the Central Bank of Russia. 


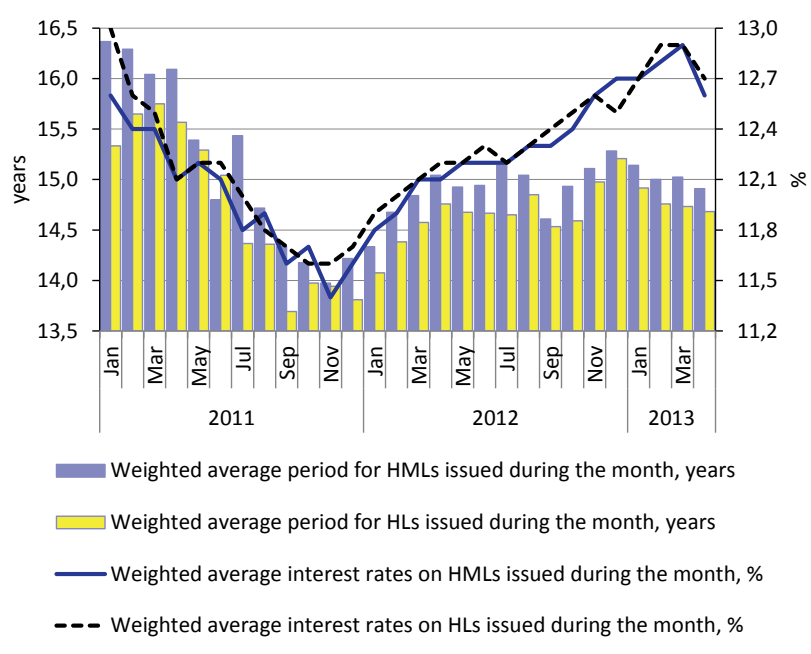

Source: based on the data provided by the Central Bank of Russia.

Fig. 8. Weighted average periods for and weighted average interest rates on ruble loans issued during the month

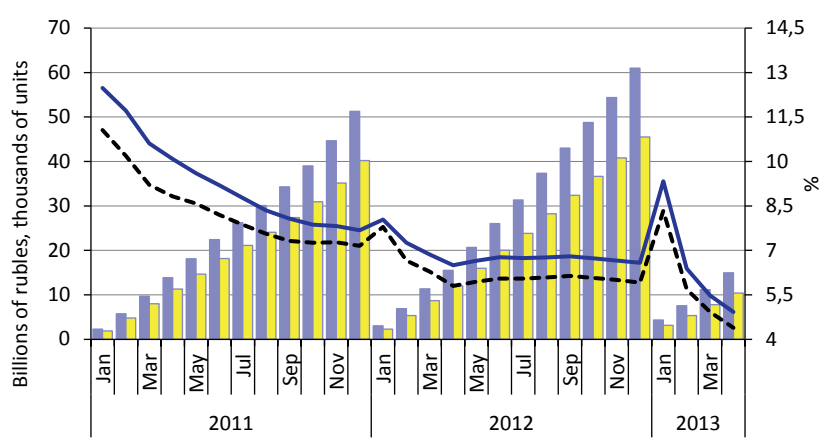

Volume of mortgage loans refinanced by AHML, year-to-date, billions of rubles $\square$ Quantity of mortgage loans refinanced by AHML, year-to-date, thousands of units - - AHML's market share in money terms, year-to-date, $\%$

_ AHML's market share in quantitative terms, year-to-date, $\%$

Source: OJSC AHML.

Fig. 9. Dynamics of ruble mortgage loans refinancing by OJSC AHML than as of May 1, 2012. As of May 1, 2013, foreign currency HMLs accounted for $1.44 \%$ of the volume of HMLs issued year-to-date, exceeding by 0.20 p.p. the value observed in April 1, 2013.

According to the Agency for Housing Mortgage Lending (AHML), as of May 1, 2013, the Agency refinanced 10404 ruble HMLs at $\mathrm{Rb} 14,977 \mathrm{bn}$, accounting for $4.92 \%$ in quantitative terms and $4.39 \%$ in money terms of the total mortgage loans issued during that period (Fig. 9). Year-on-year comparison shows that the volume of refinancing is $3.36 \%$ less in quantitative terms and $13.42 \%$ in money terms. Weighted average interest rate on refinanced in April 2013 AHML loans stood at $11.37 \%$ against $12.6 \%$ of weighted average interest rate in the same period according to the Central Bank of Russia.

Since March 2013, Sberbank, whose mortgage market share is almost $50 \%$, lowered interest rates by 1 p.p. to $12-14 \%$ p.a., whereas its minimal interest rate for special offers remained $10.5 \%$ during the summer period. The AHML and VTB 24 Bank lowered mortgage rates by 1-1.2 p.p. in May 2013. Today, interest rates stand at 7.65 to $10.75 \%$ under AHML's Maternity Capital Program, and 7.9 to $11 \%$ p.a. under Low-Rise Housing Construction and New Construction programs.

In June 2013, the Supervisory Board of OJSC AHML approved a new version of the development strategy through to 2018, under which the AHML is to focus on the development of securities market. A newly established or purchased bank is to be in charge of retirement of securities, the Agency for Restructuring of Housing Mortgage Loans (ARHML) is to be restructured into Housing and Home Finance Agency (HHFA). The foregoing strategy also provides for the development of Stimul-Ekonom sub-program designed to finance banks which finance construction of economic-class residential buildings pursuant to a priority Economy Class Housing project. The project provides for construction and sale of at least $50 \%$ of living quarters to individuals at a fixed price which is $20 \%$ lower than current market prices, but not higher than $\mathrm{Rb} 30,000$ per square meter. The HHFA is expected to issue direct guarantees to purchase unsold living quarters and provide banks with a $100 \%$ funding for housing construction. 